IRSH 47 (2002), pp. I87-2I 2 DOI: I0.1017/S0020859002000573

(C) 2002 Internationaal Instituut voor Sociale Geschiedenis

\title{
Reconsidering the East St Louis Race Riot of I917*
}

\author{
MALCOLM MCLA U GHLIN
}

Summary: This study concerns a racial massacre which took place in East St Louis, Illinois on 2 July i917. The violence erupted during a period of acute industrial unrest, and after significant black migration to the city from the South. These contexts were a focus for Elliott Rudwick's Race Riot, published in 1964, the classic study on this subject. A new approach to the context of industrial conflict is taken in the present work, one which considers the precise timing of the outbreak, and the significance of rumour in the riot. The context of community change is also reconsidered, and the underlying causes of whites' racial hostility are discussed. Close attention is given to the moment of the massacre, and an approach is taken to the social psychology of the collective behaviour of the rioters in order to offer explanations for how an entire community became involved in these atrocities.

This article concerns one of the most ferocious episodes of urban racial violence in American history, which took place in the industrial city of East St Louis, Illinois, on 2 July i917. Throughout the day, working-class whites in crowds numbering thousands rampaged through the city, beating, shooting, and hanging African Americans in the streets. Perhaps "massacre" is a better term than "riot" to describe this event, which was initiated by the white community, striking out against the minority black population. Of the forty-eight people accounted dead, thirty-nine were African Americans. Countless blacks were injured - many grievously so and large sections of the city were razed to the ground as whites sought to destroy entire neighbourhoods. This brutal event was the subject of a book by Elliott Rudwick, Race Riot, published in 1964 but largely neglected by historians since. ${ }^{\mathrm{I}}$ The present work considers the key contexts of the violence identified by Rudwick, suggests some new perspectives on the causes of the outbreak, and offers an interpretation of collective behaviour during the massacre. Reference is made throughout to a riot "mob", although social historians have tended to prefer the term "crowd" ever since George Rudé promoted its use in the analysis of popular

\footnotetext{
* I would like to thank Dr Jeremy Krikler, Dr Mary Ellen Curtin, Professor Hugh Brogan, and this journal's anonymous referees for their comments on earlier drafts of this article.

I. Elliott M. Rudwick, Race Riot in East St Lowis, July 2, 1917 (Carbondale, IL, I964).
} 
disturbances. ${ }^{2}$ Nevertheless, it will be suggested that the particular pathological qualities of the riot group in East St Louis indicate that "mob" can be a useful term to distinguish particularly brutal elements at the core of the riot from the general "crowd". Firstly, some background explanation of the riot is required.

Violence erupted in East St Louis against a background of industrial conflict across the city - most notably there was a protracted strike at the Aluminum Ore Company, the city's largest factory - and during a period of significant black migration from the South. As black migrants moved into previously segregated neighbourhoods, and were recruited by local factories during I9I7, whites began to complain that they were somehow "driving the white man out of the locality". On 28 May a mass meeting of whites, protesting against migration, ended in a nascent race riot. Many African Americans were injured that night (although nobody was killed). Sporadic racial violence flared throughout June as groups of white and black youths clashed in the streets. The atmosphere became dangerously uneasy as unfounded rumours swept East St Louis's white community that African Americans were plotting a massacre (of whites) for 4 July. ${ }^{3}$

Following this month seething with racial conflict and the threat of massacre, the July riot erupted after two local white police detectives were accidentally shot and killed by blacks defending their neighbourhood against a white gang which had driven through the streets that night, firing into black homes. Local whites struck out the following day, in revenge for the attack on the police, which they interpreted as deliberate. White crowds gathered in downtown East St Louis throughout the morning of $2 \mathrm{July}$, cheering as mobs of rioters beat, and then - in the afternoon - shot and killed African Americans. The police and the National Guard (stationed in East St Louis since the beginning of the Aluminum Ore strike) were called out to quell the riot but they simply stood back and watched, while some even joined the rioters. By the early evening, whites had razed large sections of black neighbourhoods. ${ }^{4}$ The evening reached a climax of savagery after six o'clock, as whites congregated at the junction of Fourth Street and Broadway. A large crowd of "men and women, girls and boys" were seen to "laugh" as African Americans were beaten, shot, and hanged there. Perhaps the hangings would have continued into the night, but as darkness fell Colonel E.P. Clayton of the National Guard arrived with a company of soldiers who had not been involved in the murders that day and arrested

2. George Rudé, The Crowd in History: A Study of Popular Disturbances in France and England (London, I964).

3. Rudwick, Race Riot, pp. 36-37.

4. Ibid., pp. 45-46. See also St Louis Republic, 3 July 1917, p. I. 


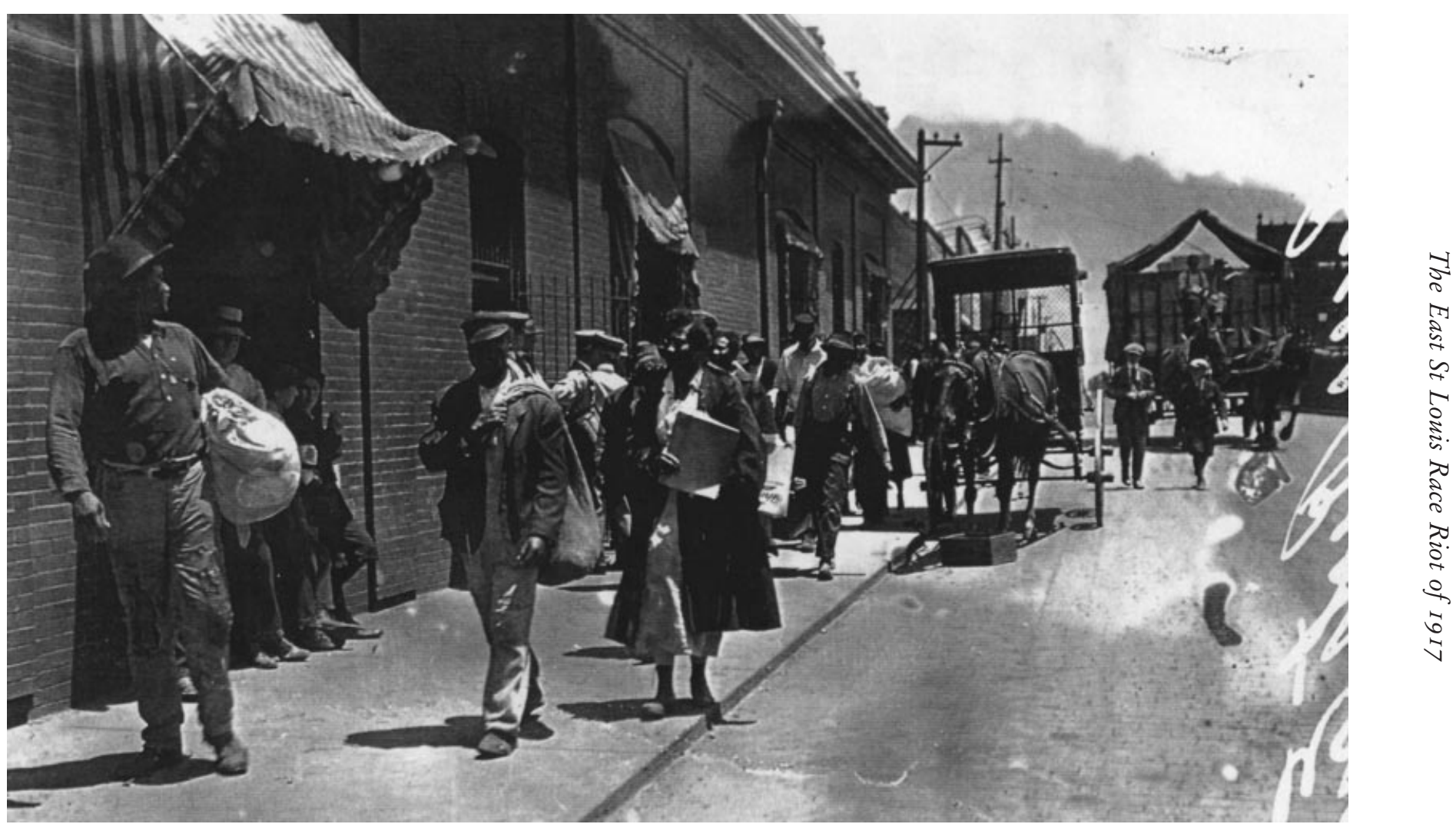

Figure I. Refugees leaving East St Louis in the wake of the violence.

Courtesy of the Chicago Historical Society, DN-68363; photograph by Chicago Daily News 
the ringleaders. Rioters continued to start fires into the night, but the violence subsided by morning.

The East St Louis massacre was remarkable for its ferocity: even the terrible race riots which consumed Chicago in the "Red Summer" of I9I9 claimed fewer lives. Why did the riot break out, and how is it that, over the course of a few hours, it seemed to engulf an entire community, either as victims or perpetrators? In his classic study, Elliott Rudwick cited migration and the Aluminum Ore strike as key contexts of the East St Louis massacre. Politicians, he argued, and later labour leaders, manipulated white fears of being displaced in the city and the labour market in the wake of defeat in the Aluminum Ore strike, in order to rally support. Certainly, Democratic-Party politicians significantly contributed to an atmosphere of racial hostility by repeatedly (and falsely) accusing black migrants of participating in electoral fraud with the Republican Party during the I9I6 general election. They insinuated that not only migrants, but indeed all African Americans in East St Louis were the accomplices of a "corrupt" Republican Party: "race and vote fraud appeared synonymous". 6 The Democrats rallied white workers in opposition to blacks by deliberately encouraging and then exploiting racial divisions, leaving - as Rudwick put it - lasting "scars" of racial hostility in East St Louis in their wake. ${ }^{7}$

Yet, where the same analysis is applied in Race Riot to organized labour, the argument is less convincing. Firstly, Rudwick's suggestion that the (predominantly white) labour leaders in East St Louis "took a leaf from the Democratic party's campaign handbook", and sought to rally white workers by expounding "anti-Negro propaganda", requires further scrutiny. ${ }^{8}$ Such an argument proposes that union leaders deliberately sought to encourage racism, to foment racial discord and division in order to rally white workers. But such a conclusion fits neither the evidence nor, for that matter, Rudwick's work as a whole. Indeed, whereas Rudwick argues that the Democrats had deliberately "misrepresented the reasons behind" black migration and its size "for political purposes" in I9I6, his suggestions about organized labour were very different, in that they did not imply premeditation: he conceded that by I917, "probably the labor

5. Report of Colonel Tripp (Illinois National Guard) 25 October 1917, Select Committee to Investigate Conditions in Illinois and Missouri Interfering with Interstate Commerce between these States, p. I3; copy of report presented to the Committee hearings (reel 6, frame I 3 of microfilm collection: M.D Frederick, The East St Louis Race Riots, University Publications of America, 1985). Hereafter, transcripts of these hearings will be referred to as Select Committee, and the microfilm collection will be referred to as UPA microfilm collection. See also St Louis Republic, 3 July i917, p. I. Also Rudwick, Race Riot, pp. 48-49, 79.

6. Rudwick, Race Riot, pp. 7-17. For quotation see ibid., p. Iо.

7. Ibid., p. I5.

8. Ibid. 
leaders believed what they were saying" when they expressed concerns about the size of - and the motivations behind - migration. Furthermore, Rudwick himself noted in Race Riot the "leadership of the [Aluminum Ore Company workers'] Protective Association recognized a need to recruit members among Negroes". On a wider scale, after the May riot, labour leaders met with prominent members of the black community and formed a committee "to promote unionization among Negroes and thereby lessen tensions between the races". A Attempting to form a common cause with African Americans was certainly not on the Democratic Party's agenda in I916. Moreover, such actions indicate that some effort was being made by both black community leaders and white labour leaders to bring black and white workers together at this time.

Rudwick clearly stated that there was "no evidence" of a union plot to cause the July riot. He nevertheless argued that labour leaders "repeatedly inflamed the whites"; that they "sponsored the May 28 protest meeting, triggering the first riot and paving the way for the second". Two points here require further consideration. Firstly, Rudwick's claim that "union officials did not demand non-violence of the rank and file when other speakers promoted mob disorder" at the meeting on 28 May, must be questioned. ${ }^{1 \circ}$ Indeed, although Rudwick noted that, "one or two speakers tried to counteract the mob spirit $[\ldots]$ by pleading with the group [...] not to attack the Negroes", he did not make the role of union leaders in this adequately clear. A look at evidence on which Rudwick based this statement - the testimony which the Central Trades and Labor Union Secretary, Edward. F. Mason, gave before the official congressional Select Committee riot investigation - reveals that it had been labour delegate C.N. Alleger together with Mayor Mollman who had been "pleading" with the white crowd not to act violently; labour leaders Michael Whallen and David Walsh made further efforts to calm the crowd. ${ }^{\text {II }}$ Furthermore, labour delegate, Earl Jimerson, also claimed to have attempted to calm the mood that night - and that he received a slap from a member of the crowd for his efforts. ${ }^{12}$ Clearly, it was union leaders who made efforts to prevent violence breaking out on 28 May, whereas Rudwick's work implies the reverse - that they had "inflamed" whites - and so tends to suggest, unfairly, that they had welcomed racial violence.

\footnotetext{
9. Ibid., pp. $8,17,23, \mathrm{I} 47$.

10. Ibid., pp. I $42-143$.

I I. Ibid, p. 28. And see testimony of Edward F. Mason, 7 November i917: Select Committee, pp. 3169, 3173 of transcripts of hearings (reel 4, frames 193, 197, UPA microfilm collection).

I2. Testimony of Earl W. Jimerson (labour union representative, East St Louis) 3I October 1917: Select Committee, p. 2033 of transcripts of hearings (reel 3, frame 87, UPA microfilm collection). See also Robert J. Baylan (reporter, St Louis Globe-Democrat) 23 October 1917: Select Committee, p. 585 of transcripts of hearings (reel I, frame 6 I I, UPA microfilm collection).
} 
Secondly, evidence indicates that conscious efforts were made by the Aluminum Ore Workers' Union to prevent racial violence in the wake of the May riot. That evidence, which offers a unique perspective, can be found exclusively in the Select Committee testimony of the Aluminum Ore Workers' Union leader, Philip Wolf. ${ }^{I 3}$ Wolf told the Select Committee that following the May riot, the mayor had, on 3I May, ordered the cancellation of an Aluminum Ore Workers' Union meeting, scheduled for that very evening to discuss the progress of the strike. It was expected that "a thousand or twelve hundred people" would attend, and if the meeting were not held Wolf feared that "they would naturally promenade up and down Collinsville Avenue", that the union "wouldn't have no control over these people at all", and that they might become involved in racial violence as others did on 28 May. He argued that "I felt safe and satisfied that if those people come down town and went into that [labour meeting] hall, that we [...] could [...] explain to them, and ask them to go home in a peaceful manner." So, Wolf recognized that racial hostility was a problem among the rank-and-file members of the union, but also that the union organization was a key instrument in efforts to prevent that hostility turning into violence. According to Wolf, during the meeting which was held despite the mayor's efforts to prevent it - the union's lawyer, a Mr Thomas, spoke first and urged the white members "to go home peacefully and not let a bad impression go out upon the Aluminum Ore strikers". He said that he "didn't believe the Aluminum Ore strikers were amongst the rioters" on $28 \mathrm{May}$, and "he didn't want them mixed up with it". ${ }^{14}$ Thus, an appeal to the best interests of the union served also as an appeal against racial violence. The union leaders were not "inflaming" white workers, but seeking to calm them. In this, the union served as an instrument to encourage discipline among white workers.

The Aluminum Ore Workers' Union recognized the importance of organizing black workers, and according to Wolf's testimony "fifteen or twenty" black members were present at the 3 I May meeting. This is not to suggest that the union was not affected by racism: Wolf noted that the black members sat "upstairs" in the hall, presumably segregated from the

I3. Testimony of Philip Wolf (union organizer, Aluminum Ore Company plant, East St Louis), 31 October 1917: Select Committee, p. 2156 of transcripts of hearings (reel 3, frame 207, UPA microfilm collection). It is accepted that, being a union representative, Wolf would have been keen to protect the reputation of his organization against any possible accusation that it might have been, in any way, responsible for the racial violence. However, we may accept the content of Wolf's testimony, discussed here. I have found no evidence that contradicts it; moreover, it sits comfortably with the actions of the Aluminum Ore Workers' Union, in seeking to recruit black members in late I9I6.

I4. Testimony of Philip Wolf, I November 1917: Select Committee, pp. 2217-2220 of transcripts of hearings (reel 3, frames 27I-274, UPA microfilm collection). 
white members. However, Wolf also claimed that after the meeting, union leaders arranged for white members to escort the black members home, to ensure that they were left in no danger from racist white gangs. ${ }^{\text {Is }}$ So, according to Wolf, the union made an effort to prevent racial hostility from spreading through its white membership, and sought to ensure that black members received the support of white against possible racial attack. While Rudwick mentioned that some African Americans joined the Aluminum Ore Workers' Union, he failed to provide any indication of the relationship between black and white union members during this critical time as racial violence simmered in East St Louis. As a result, his work tends to imply that all white union members became involved in the racial hostility of early summer of I9I7, whereas the evidence here indicates that was not so. ${ }^{16}$

Nevertheless, the actions of organized labour during this period were not uniformly admirable. Even though the Aluminum Ore Workers' Union sought to prevent racial hostility from engulfing its membership, there was racism apparent in the segregation of members at the meeting of 3 I May. Moreover, the Central Trades and Labor Union leadership's initial response to black migration was lamentable. In their pronouncements before the May riot, these key union leaders described black migrant workers in terms which suggested that they were the passive tools of capital and failed to differentiate explicitly between the perceived interests of organized labour and those of white labour. They were not sensitive to the possibility that their complaints about black migration might be misinterpreted by their predominantly white membership as an attack on black workers generally. Thus, by stating - as in the words of one union announcement - that an "influx of undesirable negroes" was bringing "no less than ten thousand" non-union black workers to the city to be "used to the detriment of our white citizens by [...] the capitalists", labour organizers in East St Louis contributed to an atmosphere of racial hostility in the city. ${ }^{17}$ It was only after they witnessed an explosion of racial hostility on 28 May that they began to see a need to bring white and black workers together. That being so, the Central Trades and Labor Union did

I5. Testimony of Philip Wolf, I November 1917: Select Committee, pp. 2219-2220 of transcripts of hearings (reel 3, frame 274, UPA microfilm collection).

I6. The role played by labour unions in Chicago's stockyards, working against racial hostility, has been discussed by James Barrett and Rick Halpern. See James R. Barrett, Work and Community in the Jungle, Chicago's Packinghouse Workers, I894-1922 (Urbana, IL [etc.], 1990), pp. 202-224. See also Rick Halpern, "Race, Ethnicity, and Union in the Chicago Stockyards, 1917-1922", International Review of Social History, 37 (1992), pp. $25-58$.

17. "Invitation to Labor Delegates", exhibit of testimony of Harry Kerr (district labour organizer) 2 November, 1917: Select Committee, p. 2570 of transcripts of hearings (reel 3 , frame 622, UPA microfilm collection). 
then seek to unite black and white workers and the evidence - on balance - indicates that organized labour sought to prevent racial hostility, not inflame it.

While qualifications can be offered in respect of aspects of Rudwick's work, he was undoubtedly correct to identify the Aluminum Ore strike and black migration as key contexts of the outbreak of racial violence. Yet, his approach does not fully grasp how the racial violence emerged out of conditions in which white workers' identity and social position appeared to them to be under threat. This will now be considered.

\section{THE ALUMINUM ORE STRIKE}

There had been other strikes in East St Louis during the I9Ios, but the Aluminum Ore strike of 1916-1917 involved the workers of the city's largest plant in a bitter and protracted dispute which was the occasion of a general drive against organized labour by employers across the city. The Aluminum Ore strike began in October 1916 after management dismissed workers organizing a union at the plant. ${ }^{18}$ That October walkout was quickly resolved: management conceded and promised to allow union members to return to work. Yet, by the spring of 1917 they had failed to fulfil that promise. A new strike was called on ig April, but this time management was intransigent, refused arbitration, and advertised the strikers' jobs. Pickets remained in place (surely out of desperation) until the end of June, before finally admitting defeat. ${ }^{19}$

Before the strike was defeated, the potential for racial confrontation arose as management sought to divide the workforce along racial lines between October and April by significantly increasing the recruitment of non-unionized Southern black migrant workers. It is surely no coincidence that it was in December, as the first black workers had begun to join the Aluminum Ore Union and traditional divisions between white and black workers were being challenged by unionization, that management began increasing recruitment of black migrants, while at the same time, over 200 whites - not all of them even Protective Association members - were dismissed. While not all of those whites were replaced by

I 8. For background detail see Rudwick, Race Riot, pp. I6-22, I42-I47. See also testimony of Philip Wolf, I November 1917: Select Committee, pp. 2168-22 I4, 2245-2263 of transcripts of hearings (reel 3, frames 22 I-268 and 297-3 I s, UPA microfilm collection).

19. Rudwick, Race Riot, pp. I6-19. For full-page advertisement, see East St Louis Daily Journal, I9 April 1917, p. 2. For strike, see Daily Journal: 19 April 1917, p. I; 22 April 1917, p. I; 23 April I917, p. I; 24 April I917, p. I, and 25 April I917, p. I. See also Harry Kerr, 3 I October I917: Select Committee, p. 1970 of transcripts of hearings (reel 3, frame 25 UPA microfilm collection). 
blacks, the larger proportion were. A racial division opened up as the dispute became entwined with opposition to the employment of black migrants as strikebreakers. ${ }^{20}$

As well as manipulating racial divisions, management unleashed a campaign of intimidation, with the threat of physical violence seemingly sanctioned by state authorities. Charles Fox, the plant manager, hired a professional strikebreaker from New York, "a large corps" of armed private "detectives", and "secretly obtained" government rifles: strikers later complained that pickets had been fired upon from within the plant. ${ }^{2 \mathrm{I}}$ At the same time, Fox drew on the support of the authorities - he obtained two companies of National Guardsmen to patrol the plant, and the East St Louis Police Department sent officers to patrol the pickets. Effectively standing with the Aluminum Ore Company against the workers, these National Guardsmen and police officers served another function for Fox: they added to the psychological pressure being exerted against the strikers. He used the fervently patriotic moment of America's entry into the First World War - which coincided with the strike - to portray the strikers as traitors, whom the government was seeking to destroy. Repeatedly in newspaper interviews, and during injunction proceedings in court, management publicly accused the strikers of being "pro-German" and treasonous "alien enemies". ${ }^{22}$ In a move that seemed designed to convince labour leaders that the government was actively supporting Aluminum Ore, Charles Fox told the Daily Journal - which stated this on its front page, on two occasions - that federal government agents had been "stationed in the ore plant" for some time, that strikers were "constantly under espionage", and even "under the surveillance of the secret service". ${ }^{2} 3$ This strategy was not simply intended to influence public opinion: management wanted to intimidate the strikers themselves. For example,

20. Rudwick, Race Riot, pp. 16-17. As both James Barrett and Rick Halpern found, in their work on Chicago's stockyards, unions were generally able to recruit both black and white native Chicagoans, but faced particular problems when trying to recruit black migrants from the South - many were deterred from joining unions after having experienced racist Southern unions. They also note how employers played a key role in dividing their workforce racially, fomenting racial discord. See Barrett, Work and Community in the Jungle, pp. 202-224; and Halpern, "Race, Ethnicity and Union", pp. 25-58.

21. Rudwick, Race Riot, p. I8. Also Daily Journal, 23 April I917, p. I. See additionally testimony of E.M. Sorrells (superintendent, Aluminum Ore Company) I 2 November 1917: Select Committee, p. 3926 of transcripts of hearings (reel 4, frame 957, UPA microfilm collection).

22. Rudwick, Race Riot, pp. I8-19. Also Daily Journal, i9 April I917, p. I, and 23 April I917, p. I.

23. For "stationed [...]" and "constantly [...]" see Daily Journal, i9 April I917, p. I. For "under surveillance [...]” see Daily Journal, 23 April r917, p. I. 
one company supervisor threatened strike leader Philip Wolf that spies could "find out news out of your own bedchamber". ${ }^{24}$

This confrontation soon spread across the city, affecting workers at other factories: at least one other group of organized workers - the US Steel workers who struck on the same day as the Aluminum Ore workers - were also publicly accused of being "pro-German" in the press. One rumour circulating at this time held that "secret servicemen" were in place to "intimidate the workers" across East St Louis and it is not surprising that such fears arose, when unions at more than one factory were being publicly denounced and (apparently) targeted by government agents. ${ }^{25}$ Furthermore, as Rudwick noted, the presence of the National Guard deployed around a number of factories and bridges was surely a gesture of intimidation to organized workers across the city. Indeed, streetcar workers were told directly by management that if they went on strike, the Guard would be on hand to provide strikebreaking labour. ${ }^{26}$

White workers across the city felt themselves in the grip of an onslaught by employers, state and federal authorities. Significantly, at that moment, those National Guardsmen who had been deployed against (predominantly white) organized labour were also detailed to protect and escort black strikebreakers. It was becoming clear that capital and state were not only aligning the strikers with America's war enemy, but also bringing to bear against them powers reserved for use against such an enemy. And white workers felt alienated precisely as black strikebreakers appeared protected by the state. Rudwick drew attention to - but left unexplored the timing of the violence. Violence simmered as the Aluminum Ore strike continued, with pickets desperately but hopelessly in place through June. It was soon after this prominent strike at the city's largest factory was crushed by state and capital - organized labour's cause as a whole seemingly crushed with it - that violence erupted in a brutal massacre. ${ }^{27}$ This requires further discussion.

It was at this precise time that unfounded rumours of a black plot to massacre whites on 4 July emerged. It is possible to draw connections between the industrial conflict, the timing of the emergence of false rumours, and the outbreak of racial violence. Such an approach has been suggested by Jeremy Krikler in a recent article about a South African racial massacre, in which he made tentative comparisons with East St Louis. A strike by white miners on the South African Rand in 1922 was facing defeat

24. Testimony of Philip Wolf, I November 1917: Select Committee, p. $217 \mathrm{I}$ of transcripts of hearings (reel 3, frame 224, UPA microfilm collection).

25. For US Steel, see Daily Journal, ig April 1917, p. I. For rumours, see testimony of Alois Towers (labour representative, East St Louis) 2 November 1917: Select Committee, p. 2455 of transcripts of hearings (reel 3, frame 507, UPA microfilm collection).

26. Rudwick, Race Riot, p. I9.

27. Ibid., pp. 36-37. 
and state forces flooded the region to repress the strikers: "all out combat with the full might of the state" seemed impending. At that moment, white workers broke out into indiscriminate racial violence, attacking even blacks not associated with the mines. ${ }^{28}$ Significantly, prior to the military conflict between the white working class and the state, there arose a series of unfounded rumours of an impending black uprising. White strikers then began to appeal (although unsuccessfully) to those state forces which had been ranged against them, offering assistance in putting down this "insurrection". ${ }^{29}$ Such rumours were no simple pretence upon which white strikers sought to avoid confrontation with the authorities. Rather, there was a "genuine fear" among the whites: they believed these (false) rumours and Krikler suggested that they might be used "in the way a psychoanalyst would dreams: as labyrinthine expressions of hopes and wishes". As the white community was fractured by class conflict - white workers driven from their privileged position in the racial state - rumours arose spontaneously from a subconscious desire to unite all whites against supposedly threatening racial others..$^{30}$

It is surely significant that as white workers in East St Louis were coming under attack as "alien enemies", rumours of a black uprising planned for 4 July - America's National Day - began to take hold. ${ }^{3 \mathrm{I}}$ Further rumours emerged during the riot that an arsenal, ready for use in a black uprising, was hidden at the home of Dr Le Roy Bundy, a prominent black community leader. Others warned of an impending attack from the neighbouring black village of Brooklyn. Most extravagantly: "word reached East St Louis that the negroes of Belleville, Brooklyn, Cahokia, Alton, Granite City and East Carondelet were mobilizing to invade the city". ${ }^{2}$ Such rumours were undoubtedly false. National Guardsmen awaiting "armies" of blacks stated later that "everything was quiet; we had

28. Jeremy Krikler, "The Inner Mechanics of a South African Racial Massacre", The Historical Journal, 42 (1999), pp. 1051-1075, 1067-1068.

29. Ibid., pp. 1068-1069.

30. Ibid., pp. 1068-107I.

31. For rumours, see Rudwick, Race Riot, p. 37. See also testimony of Roy Albertson (reporter, East St Louis Daily Journal) 22 October I 91 7: Select Committee, p. 477 of transcripts of hearings (reel I, frame 50I, UPA microfilm collection).

32. For "arsenal", see testimony of Thomas L. Fekete (attorney, East St Louis) I6 July i9i7: Military Board of Inquiry, p. 22 of transcripts of hearings (reel 7, frame 205, UPA microfilm collection). See also Report to Governor, by Colonel S. O. Tripp, Race Riot, East St Louis, Illinois, 25 October 1917, pp. 9-I2 (reel 7, frames 9-I2, UPA microfilm collection). Additionally, Captain J.A. Eaton (Illinois National Guard) i6 July 19 17: Military Board of Inquiry, p. I35 of transcripts of hearings (reel 7, frame 227, UPA microfilm collection). For invasion rumour, see East St Louis race riot newspaper clipping file, Missouri Historical Society: p. I8, "Saloons Get Orders". 
no trouble". ${ }^{33}$ Yet there was undoubted sincerity of belief: the St Louis Republic reported that when rumours of a black invasion reached one white section of East St Louis, "genuine fear was apparent among the women and children who blockaded themselves in their homes". ${ }^{34}$ Importantly, in East St Louis as on the Rand, the rumours enabled white workers to appeal to the forces that had until then stood against them. The shooting of the white policemen - Sam Coppedge and Frank Wadley - on the night before the July riot was certainly accidental, but white workers asserted that the killings were deliberate. The police had been set against white workers - deployed to patrol the Aluminum Ore strike - but on 2 July, white rioters stormed black neighbourhoods shouting "They got Sam and Frank; we'll get them", claiming to be acting in revenge on behalf of the police. ${ }^{35}$ Such actions appealed to a common whiteness in opposition to a putative "threatening" black community, which tended to obscure divisions within the white community.

In cooperation between the rioters and the National Guard, the resolution of conflict within the white community had its most dramatic manifestation. On 2 July, rumours of a black threat diverted Guardsmen from quelling the riot. When a military inquiry asked the National Guardsman Captain J.A. Eaton, "[during the riot] did you establish a line of patrols?", he replied: "No sir. We just simply held the bridge [to Brooklyn]." His reason: "it had been rumoured there was a bunch of blacks coming from Brooklyn to clean the [white] people out". But no such attack happened. ${ }^{36}$ This is significant. Not only were rumours diverting soldiers from protecting African Americans, but (as Krikler implied for East St Louis) this represents a dramatic change: whereas the presence of the National Guard had previously signified that the authorities had designated white workers as a threat, the Guard were now being deployed to protect whites from blacks.

National Guard deployment on 2 July thus promoted in the minds of white workers the resolution of the fracture in the white community. Of equal significance were the actions of individual Guardsmen, who actually assisted the rioters and were seen firing at blacks. ${ }^{37}$ It was as if a sense of camaraderie was being forged between these two previously opposed groups as they joined together in the murder of blacks. Soldiers were seen "fraternizing with the mob, smoking cigarettes with them and accom-

33. Testimony of Captain J.A. Eaton, I6 July 1917: Military Board of Inquiry, p. I35 of transcripts of hearings (reel 7, frame 227, UPA microfilm collection).

34. Missouri Historical Society clipping file: p. 18, "Saloons Get Orders".

35. See also Rudwick, Race Riot, p. 45 .

36. Testimony of Captain J.A. Eaton, I6 July i917: Military Board of Inquiry, p. I35 of transcripts of hearings (reel 7, frame 227, UPA microfilm collection).

37. Rudwick, Race Riot, p. 75. See also St Louis Globe-Democrat, 3 July I917, p. 8. 
panying them on their errands of brutality". ${ }^{3}$ Perhaps the white National Guardsmen were as keen as the white workers to resolve the divisions. They were overheard encouraging the violence: one, for example, was heard telling a rioter he could "kill all the niggers" as far as he cared. 39 There was a gruesome jocularity about the riot - one witness referred to a "circus" atmosphere. Perhaps that jocularity, the laughter accompanying many of the atrocities, was a manifestation of relief felt when fears about the National Guard were overcome by common participation in the riot. ${ }^{\circ}$ On at least one occasion after soldiers had shot blacks, rioters "slapped their thighs and said the Illinois National Guard was all right". ${ }^{4}$ The fractured racial community was being healed.

Surely it is no coincidence that as the white working class in East St Louis was crushed by state and capital, unfounded rumours of a black threat emerged, prompting white workers to ally with the forces which earlier had been set against them. It is powerful evidence indeed that in East St Louis (as Krikler demonstrated for the Rand, and suggested of East St Louis), unfounded rumours of black revolt were "linked subconsciously to an attempt to restore [a white racial community]". ${ }^{42}$ Consideration of the relationship between industrial conflict, community fracture, and the emergence of rumour around the riot reveals aspects of the outbreak of violence and its causes that Elliott Rudwick had not discussed. However, the question of community change must also be addressed.

\section{COMMUNITY CHANGE AND THE RACE RIOT}

Between I9I0 and I9I7, the black population of East St Louis doubled, as many migrants moving from the South to northern industrial cities - a demographic trend known as the Great Migration - settled in East St Louis. ${ }^{43}$ Although migration was significant, blacks came to be only approximately Io or I 5 per cent of the total population of East St Louis, at the most about I 3,000 people as a whole by July i 917.44 However, white East St Louisans began to fear that their urban world was being disrupted

38. Missouri Historical Society clipping file: p. 25 , "Soldiers Smoke". See also St Louis PostDispatch, 3 July i917, p. 2. Additionally, Rudwick, Race Riot, pp. 74-77.

39. For this and further example, see testimony of Paul Y. Anderson (reporter, Post-Dispatch) 20 October 1917: Select Committee, pp. 258, 262 of transcripts of hearings (reel I, frames 288, 292, UPA microfilm collection).

40. For "circus" see Rudwick, Race Riot, p. 44. See also St Louis Republic, July 3 1917, p. I.

4I. Rudwick quotes Daily Journal, 5 July 1917. See Rudwick, Race Riot, pp. 47-48.

42. Krikler, "Racial Massacre", p. 1072.

43. Rudwick, Race Riot, pp. I57-173. For a discussion of the Chicago context, see H.R. Clayton, Black Metropolis (London, 1946), pp. 58-64. Figures derived from Rudwick, Race Riot, pp. 5, I57-173.

44. Rudwick, Race Riot, pp. I63-166. 
by black migration, perhaps even lost in some sense to the newcomers. Whites said that "the streets were full" of black people, that East St Louis would become - in the words of one white - a "negro town".45 They sought desperately to maintain neighbourhood segregation, and in the months before the race riot there were numerous protests in white neighbourhoods, seeking to prevent blacks moving in. ${ }^{46}$ Ironically, white racists' intolerance of sharing neighbourhoods with blacks accelerated the breakdown of such neighbourhoods: according to the East St Louis real estate agent Thomas Canavan, "as soon as" a black resident moved into a white neighbourhood, "the white people [in that street] would move out". Market Avenue, was apparently one such street where this had occurred by July I9I 7 it was known as a black neighbourhood. ${ }^{47}$ It seems likely that, because of their prejudices, the shifting racial configuration of East St Louis neighbourhoods left white workers feeling insecure and disoriented.

The context of community change does indeed seem to be a key one - in respect of whites' perceptions of, as much as actual change, for they greatly overestimated the numbers of African Americans arriving in the city during this period. At the time whites believed that as many as I 5,000 blacks had arrived in the city since 1916, or even that 12,000 had arrived in early i917. If this had been true, African Americans would have composed 30 per cent, rather than is per cent of the total population. Rudwick suggested that whites became confused about the migration, when they mistook African Americans, stopping briefly in East St Louis en route to other northern cities, for people planning to settle in the city. $4^{8}$ This helps explain why whites overestimated the size of, but does not explain why whites reacted in a hostile way to, migration. Moreover, it was not strictly being outnumbered by blacks that whites feared, but - as the tendency of whites to abandon neighbourhoods when a black resident moved in indicates - having their racially exclusive enclaves in their minds somehow "compromised" by the presence of blacks.

Seeking to explain the underpinnings of such attitudes regarding segregation, certain writers have noted that white racists have, in the past, often associated blackness with dirt, pollution, disease. ${ }^{49}$ This is worth

45. For "streets" see ibid., p. I6r. For "negro town" see testimony of Philip Wolf, r November I917: Select Committee, p. 23 I7 of transcripts of hearings (reel 3, frame 368, UPA microfilm collection).

46. Testimony of Edward F. Mason, 7 November i 9 17: Select Committee, p. 3 I 20 of transcripts of hearings (reel 4, frame I4I, UPA microfilm collection). See also Rudwick, Race Riot, p. 24. 47. Thomas J. Canavan (real estate agent, East St Louis) 27 October i917: Select Committee, pp. I473-I474 of transcripts of hearings (reel 2, frames 553-554, UPA microfilm collection).

48. Rudwick, Race Riot, pp. I58, I6I-163.

49. See, for example, Joel Kovel, White Racism: A Psychobistory (New York [etc.], I988 (1970)). See also Winthrop Jordan, White Over Black: American Attitudes Towards the Negro, I550I 8 I2 (Chapel Hill, NC, I968). 
considering because in East St Louis, prior to the race riot, a rumour that a smallpox epidemic was being spread by blacks circulated within the white community - precisely at the time when whites' anxieties over the erosion of segregation were becoming acute, this bogus fear of actual "pollution" by blacks emerged. The rumour was almost certainly incorrect: of the twenty-five cases of smallpox recorded by i 2 February 1917, only six were among black patients, but by April I9I7 newspapers were claiming that "most cases", and by May, "practically all" cases were among migrants. ${ }^{5 \circ}$ Indeed, the Chicago Commission on Race Relations in 1922 concluded that the 1917 "epidemic" in East St Louis was "imaginary, one of the many rumours or myths circulated in periods of racial tension". ${ }^{\text {II }}$ Rudwick drew attention to the way in which the number of black smallpox patients was overestimated and argued this was done to inflame whites. But he did not consider the possibility that these rumours were believed sincerely and reflected anxieties about pollution associated in the minds of whites with race: yet as the Chicago Commission suggested, white anxieties about race have often been accompanied by fears of disease.

During the massacre, such concern about smallpox arose when African Americans were offered shelter in City Hall. Local whites considered East St Louis a "white man's town", and the sheltering of black refugees in a symbol of local citizenship like City Hall must have been perceived as a racial transgression of some sort. Significantly, on 4 July, the St Louis Globe-Democrat reported the rumour that "cases of smallpox" were found among the "several hundred" black refugees sheltering in City Hall. While the evidence indicates that the majority of smallpox victims were white, it was the presence of black refugees that raised a panic, and elicited reassurances that City Hall would be "fumigated" once the refugees had gone, in a purification ritual which seems to have had more of a psychological meaning than practical purpose. ${ }^{52}$

The recurring use by the East St Louis rioters of phrases such as having "wiped out" and "clean[ed] up" neighbourhoods to describe their actions seems to fit with the idea that whites felt they were removing what they considered to be a pollutant from their midst - inasmuch as their language reflected such notions. Likewise the widespread burning of the bodies of African Americans and of their homes. Colonel Tripp, Adjutant General of the Illinois National Guard, commented at the time that whites sought not only to kill blacks, but also "to burn them out of their respective

50. Testimony of Alois Towers, 2 November i917: Select Committee, p. 2393 of transcripts of hearings (reel 3, frame 446, UPA microfilm collection). See also Rudwick, Race Riot, p. 274. This is an alternative interpretation of his figures.

51. Rudwick, Race Riot, p. 274.

52. For "white man's town" see ibid., p. 28. For "fumigate" see Missouri Historical Society clipping file: p. 27, "Barefoot and in Rags". 
districts". Indeed, approximately 200 homes were destroyed by fire. ${ }^{53}$ Witnesses testified to the dead or dying being thrown into burning buildings. The rioters remained proud of what they had done in the weeks after the riot and the burning of bodies was no simple attempt to destroy corporeal evidence of crime. 54 Not satisfied with killing, they wanted to erase even dead bodies. Fire has many symbolic associations, but that of its use in the burning of corpses during epidemics seems pertinent here: during the East St Louis riots, perhaps by fire whites sought, in their minds, to "decontaminate" areas of the city "polluted" by the presence of blacks.

However, while it is possible to identify ways in which racial violence condensed around such notions of pollution this approach cannot account for the social context of whites' fear of sharing urban space with blacks. This must also be considered.

Recent scholarship has drawn attention to the way in which white workers have formed a sense of their own self-esteem by comparison with the social status of blacks. 55 In the emerging debate over the fruitfulness of this scholarship, a call has been made for case studies to be undertaken regarding its central thesis. It seems confirmed by evidence from East St Louis. ${ }^{56}$ During the Select Committee hearings, for example, one white witness stated that it was believed that blacks did not aspire to the same standard of living said to be appropriate for white workers. Although both whites and blacks generally endured insecure employment and poor housing, black workers were said to be unperturbed ("don't care") about receiving charity, or living "in a shack". 57 Of course, such notions were

53. For "wiped" see testimony of Paul Y. Anderson 20 October i 917: Select Committee, p. 25 I of transcripts of hearings (reel I, frame 28 I, UPA microfilm collection). For "clean" see St Louis Republic, 3 July i917, p. 5. Tripp's comments from Report to Governor, by Colonel S. O. Tripp, 25 October I9I7, p. 20 (reel 6, frame 20, UPA microfilm collection). See also Rudwick, Race Riot, p. 48 .

54. Testimony of George E. Popkess (reporter, St Louis Times) 22 October 1917: Select Committee, p. 399 of transcripts of hearings (reel I, frame 427, UPA microfilm collection). See also C. Cuakenbush, I6 July 1917: Military Board of Inquiry, p. 225 of transcripts of hearings (reel 6, frame 317, UPA microfilm collection). See also Rudwick, Race Riot, pp. 4I-57, 67.

55. See David R. Roediger, The Wages of Whiteness: Race and the Making of the American Working Class (London [etc.], I991); in particular, see pp. I 2- I3, 65-94. While Roediger's work dealt largely with the antebellum South, the suggestion that white workers constructed their identity with reference to notions of the social position of blacks has persuasive power beyond that era and context.

56. See James R. Barrett, "Whiteness Studies: Anything Here for Historians of the Working Class?", also Eric Arnesen, "Whiteness and the Historians' Imagination", International Labor and Working-Class History, 60 (Fall 2001), pp. 33-42, 40, and pp. 3-32.

57. For quotation see Thomas J. Canavan, 27 October i 917 : Select Committee, pp. I482-1483 of transcripts of hearings (reel 2, frames $562-563$, UPA microfilm collection). See also Rudwick, Race Riot, p. I I. See A. Towers, i November i 917: Select Committee, p. 2376 of transcripts of hearings (reel 3 , frame 427 , UPA microfilm collection). 
bigoted white assumptions about black aspirations, but if white workers could point to a notional black worker who suffered economic insecurity and privation, yet remained satisfied with such, it created an ideological difference: the basis on which whites could reassure themselves that because only they had the aspiration to improve their standard of living, they somehow had a claim on a relatively higher social status, that there was a potential for social and economic mobility. This was, however, simply an ideological difference, and segregation was important for whites for this reason if no other: it provided the physical separation from those they sought ideologically to be utterly dissociated from, yet in reality were approximate to in economic position.

This had particular significance as organized labour was crushed in the weeks before the July massacre. In their hundreds, white workers (economically insecure at the best of times) could be overheard telling each other in public how they feared that they would be forced to live "like a nigger". ${ }^{8}$ Perhaps by such oft-exchanged statements whites sought to reassure themselves of an ideological difference from blacks, at a time when they feared social and economic approximation with them. Indeed, during the July massacre, such utterances became a frenzied call as the crowd was led at one point by one man shouting "one race born black, should be exterminated [...]. We're born white, and we'll always be white!" 59 There would have been no need to state, "we'll always be white", unless there was a palpable feeling that whiteness was not a stable identity, and might be lost.

The approaches suggested here offered new explanations of the outbreak of racial violence on 2 July i917. Moving beyond Rudwick's observations, an attempt has been made to understand the underlying causes of the descent into violence. Next, consideration will be given to the violence of the riot mobs and the social and psychological processes structuring the riot, for on this, Rudwick's work is silent.

\section{COLLECTIVE BEHAVIOUR AND THE RACIAL MASSACRE}

It is particularly disturbing to reflect that thousands of men, women and children were present at and supportive of the extreme acts of violence during the East St Louis massacre. How did the massacre develop into such a brutal outpouring of violence and how could apparently ordinary white working-class people eagerly take part? Elliott Rudwick provided an evocative and compelling narrative of the riot, but did not seek to address this question. However, by considering the collective

58. Thomas J. Canavan, 27 October 1917: Select Committee, p. 1482 of transcripts of hearings (reel 2, frame 562, UPA microfilm collection).

59. St Louis Republic, 3 July 1917, p. 5. 
sociopsychological process of the riot, a deeper understanding of how it spiralled into a bloody, sadistic massacre can be obtained.

In order to do so it is necessary to consider the structure of the riot, which evidence indicates consisted of a large spectating crowd surrounded a murderous core, in which "a comparatively small number of people [were] doing the assaulting". Evidence indicates that the core acted as a form of leadership: that "no better organized mob ever operated"; that rioters divided into "units [...] each [...] [of which] [...] appeared to have a leader". ${ }^{60}$ Accordingly, in this analysis, distinction will be made between the wider supporting "crowd", and the actively violent "mob" core. Particular attention will be given to the role of these riot leaders.

Moments of spontaneous popular racial violence, such as the East St Louis massacre, have not been a central concern of much recent theoretical work on crowd action - it has instead focused on sustained social movements, strikes, revolutions, and related political movements. However, passing moments like the East St Louis massacre seem to stand apart from politically driven, sustained movements. ${ }^{6 \mathrm{I}}$ An approach that might address the features of the East St Louis massacre - one which offers an interpretation of the behaviour of the crowd and of the role of riot "leaders" - is suggested by work on collective behaviour and socialpsychological group processes. ${ }^{62}$ In particular, it seems worth giving consideration to the "emergent norm" approach to collective behaviour, an approach which seems most comfortable with an event like this: a spontaneous and temporary, passing moment; a moment in which the "everyday" rules of behaviour did not apply.

60. Testimony of Robert J. Baylan, 23 October 1917: Select Committee, p. 6r9 of transcripts of hearings (reel I, frame 644 UPA microfilm collection). Additionally, see Rudwick, Race Riot, pp. 44-47, 225 . See also report of Colonel Tripp 25 October 1917: p. I3 of copy of report (reel 6, frame I3, UPA microfilm collection). See also St Louis Republic, 3 July 1917, p. I. For descriptions of leadership, see ibid.

6r. In this field, for example, Doug McAdam, Sidney Tarrow, and Charles Tilly have recently offered a wide-ranging consideration of approaches to crowd action and contentious politics in a variety of contexts. However, their work does not seem applicable in this case. The examples of collective violence in their work which hold most promise for a comparison with East St Louis the Rwandan genocide, or Hindu-Muslim violence in South Asia - have connections with wider sustained political movements. Furthermore, in the outbreak of violence, East St Louis conforms more to the "threshold effect", which McAdam, Tilly, and Tarrow have acknowledged but did not seek to address, and seems to stand apart from the concerns of their work on that basis as well. See Douglas McAdam, Sidney Tarrow, and Charles Tilly, Dynamics of Contention, (Cambridge, 200I), pp. I26-I5I, 306-307, 337-340. See also Sidney Tarrow Power in Movement, Social Movements and Contentious Politics, 2nd edition, (Cambridge [etc.], 1998), pp. 6, I4. See also the comments of Paul Brass in his Theft of an Idol: Text and Context in the Representation of Collective Violence (Princeton, NJ, 1997), pp. 9-10. Brass also considers the significance of riot leaders.

62. See Ralph H. Turner and Lewis M. Killian, Collective Behaviour (Englewood Cliffs, NJ, 1972) and Rupert Brown, Group Processes: Dynamics Within and Between Groups (Oxford [etc.], I988). 
The emergent norm approach suggests that within a temporary closed crowd environment, such as the East St Louis massacre, the judgements people make tend to be influenced by others in their vicinity. Their judgements become influenced by the norm of behaviour established by the majority of the crowd. Experiments have indicated a tendency for people who dissent from majority opinion in a collective group to remain silent, giving the impression of unanimity within the group; moreover, dissenters often find themselves "experiencing doubts about their own judgement" in reference to others acting in a self-assured way. ${ }^{63}$ Further work on the social psychology of groups has suggested that assertive leaders can actually shape new norms of behaviour by acting in a "consistent and convincing" manner. ${ }^{64}$ Assertiveness tends to discourage dissent and this creates the impression of majority support, lending a sense of legitimacy, thus encouraging unity of behaviour.

Such an approach suggests that with a bold leading figure or subgroup acting consistently and with vigour, the crowd on 2 July came to accept greater and greater acts of violence. The tendency to conformity - for individuals to accept as the norm the behaviour of a perceived majority suggests that the crowd may have been drawn into accepting behaviour that might otherwise have been considered too extreme. Simply put, whites in East St Louis got "caught up in the mood" of the riot. Furthermore, it places emphasis on the leading riot "mob" core: they physically orchestrated the violence, shaping and reshaping norms of behaviour in the riot, driving it forward.

If such theories hold true for the July massacre, then it would be expected that violence increased incrementally and evidence does indeed suggest this was so. The journalist and eyewitness, Roy Albertson noted, "As the day wore on, the rioting grew more serious". Although the day would end in an orgy of sadistic, ritualistic murders, shootings, and hangings at Fourth and Broadway, the riot began with the generalized beating of passersby, before attacks were "ratcheted up". Over the day, attacks became increasingly focused on killing - not simply beating - and involved increasingly systematic searches for African Americans. However, between 9 and Io o'clock in the morning it was noted that the rioters "were just running around [...] promiscuously from one end of the street to the other [...] [and] they would get tired of beating up negroes there and they would look for some new game [at the other end of the street]". ${ }^{65}$ These rioters surely carried out vicious beatings, but during this first hour

63. Turner and Killian, Collective Behaviour, pp. $2 \mathrm{I}-24$.

64. Brown, Group Processes, pp. I03-I 2 I.

65. Testimony of Roy Albertson, 22 October 1917: Select Committee, p. 489 of transcripts of hearings (reel I, frame 5I3, UPA microfilm collection). See also Rudwick's descriptions: Rudwick, Race Riot, p. 46. 
their attacks - with an emphasis on "beating up" - do not betray the specifically murderous intent evident later in the day.

Amongst themselves, from the outset, the first rioters were saying that black East St Louisans should be "wiped out", but they did not act on this for some time. ${ }^{66}$ However, at 10 o'clock, as the rioters were still ranging around, "two or three" rioters from a crowd of approximately thirty, broke away as they passed a black man on Collinsville Avenue: they beat him and then one of the white men drew a pistol and shot him. The African-American man survived and was soon after taken to hospital by an ambulance. Within fifteen minutes, another black man was fired upon although this time the white rioter missed. Clearly, some members of the riot were willing to commit acts which indicate homicidal intent. Yet these two shootings seem exceptional, stand out as untypical of the violence that morning, and indeed they occurred at a point before the riot had taken shape, before it had any focus, and before the large spectating crowd had formed. ${ }^{6}$

As that crowd - of possibly 500 or 1,000 spectators - gathered over the course of the morning, beatings - but not homicidal attacks - were the norm. White rioters began stopping streetcars, searching them for black passengers, dragging out those they found, and beating them with brickbats. There were no fatalities before I o'clock, but the attacks stopping cars and searching for victims - were becoming more systematic, organized by active rioters. Then, soon after I o'clock, two wagon drivers, Charles Hanna and John Dow, who were leading the assaults, dragged Edward Cook and his foster son from a streetcar and shot and killed them both. From that point a new murderous intent became established in the riot. It seems that an almost casual attitude developed towards murder once the behavioural boundary had been crossed: in the early afternoon, rioters "calmly" shot and killed prone victims. ${ }^{68}$ And while these core rioters broke increasingly brutal ground, the crowd followed behind them, not participating, but cheering and "hissing" at dissenters to maintain unanimity. ${ }^{69}$

66. Testimony of Paul Y. Anderson, 20 October 1917: Select Committee, p. 25 I of transcripts of hearings (reel I, frame 28I, UPA microfilm collection).

67. Testimony of Paul Y. Anderson, 20 October 1917: Select Committee, p. 252 of transcripts of hearings (reel I, frame 282, UPA microfilm collection). See also testimony of Roy Albertson, 22 October 1917: Select Committee, p. 489 of transcripts of hearings (reel I, frame 513, UPA microfilm collection).

68. Rudwick, Race Riot, pp. 44, I03-106. See also testimony of Dr C.P. Renner (coroner, East St Louis) 26 October 1917: Select Committee, pp. 1230, I249 of transcripts of hearings (reel 2, frames 3 14, 333, UPA microfilm collection). For crowd size, see testimony of Paul Y. Anderson, 20 October 1917: Select Committee p. 253 of transcripts of hearings (reel I, frame 283, UPA microfilm collection).

69. Rudwick, Race Riot, pp. 44-45. 
Then, after 3 o'clock, rioters moved south into the black neighbourhood around Third Street. According to a newspaper report, white police officers standing amongst the crowd told the riot leaders that they should loot a nearby pawnshop for weapons: the rioters let it be known that the police were encouraging further violence, allowing them to claim their actions were somehow legitimate, which surely strengthened a sense within the riot that such behaviour was the norm. Not long after, violence escalated: rioters set fire to buildings around Third Street and South Main Street, and shot African Americans as they fled from their homes there. Now rioters were not simply opportunistically attacking black passersby but seeking out people to kill. Again the crowd was drawn after, supporting the mob core: at one point - support blurring into participation - a group of teenage girls assisted armed men in the chase after a fleeing black woman, demanding the men shoot her, although these girls did not assault the woman themselves. ${ }^{70}$

As these assaults on black homes began, the riot promised to become even more murderous. Around that time, at 3.45 in the afternoon, there was a confrontation between a National Guardsman and a white rioter. The Guardsman asked the rioter to stop beating a man, saying that he had "done enough to this man", and not to kill him. This plea for restraint seems to have reflected the tacitly agreed bounds of violence for the riot in the morning, but the riot had by now broken more murderous ground. Rather than complying with the Guardsman, the rioter "immediately" drew a pistol defiantly from his pocket and shot the beaten man through the head. Murder was now the established norm, and the National Guardsman's attempt to reimpose the earlier pattern of behaviour failed in the face of the assertive rioter. ${ }^{7 \mathrm{I}}$

During the afternoon, as well as becoming more severe, it would appear that the scope of the violence also widened. The mob at first hesitated about killing women. Indeed, two mobsmen came to blows with their fellows, defending a black woman streetcar passenger at one point. ${ }^{72}$ And when the first attacks on black neighbourhoods began, after $3.30 \mathrm{pm}$, rioters shot and killed men as they fled from the burning buildings, but they did not shoot children..$^{73}$ Yet the climax of the riot on Fourth and Broadway after 6 o'clock, would engulf women and even children: a young boy was thrown into a fire to die; a one-year-old child was shot in the

70. Globe-Democrat, 3 July, I9 17, p.8. See also St Louis Republic, 3 July I 917, p. I. Additionally, see Rudwick, Race Riot, pp. 46-47.

7I. Testimony of Paul Y. Anderson, 20 October 1917: Select Committee, pp. 253-258 of transcripts of hearings (reel I, frames 283-288, UPA microfilm collection).

72. Rudwick, Race Riot, pp. 103-106. See also St Lowis Republic, 3 July 1917, p. 5.

73. Testimony of Paul Y. Anderson: Military Board of Inquiry, p. 33 I of transcripts of hearings (reel 6, frame 424, UPA microfilm collection). 
head; and a three-year-old girl was shot in the head and left dead next to men who had shared the same fate. ${ }^{74}$

By early evening, the brutal element was holding sway, controlling the riot at the "storm center" of Fourth and Broadway, where the greatest atrocities occurred. It was after 6 o'clock, at the height of the violence, that the news reporter Paul Anderson, for example, saw a rioter sit on a black man and shoot not one, but "several shots" into that man's head; one victim was shot in the face and then hanged; another was hanged and then shot twice in the head. There seems also to have been a degree of sadistic delight, which shocked watching reporters: a man being hanged was teased with "good natured jabs in the ribs" as a noose was placed around his neck. 75

The spectators did not commit atrocities themselves. The leadership core orchestrated proceedings. That is not to say that the core members were the only ones to commit acts of violence: on one occasion, for example, a group of teenage girls took part in a beating, as if sampling the riot experience. The girls beat a black woman so badly they got her blood on their clothes, but then calmly walked away, rejoined their friends in the crowd and discussed what they had done. ${ }^{76}$ Yet, such evidence reinforces the view that the worst of the violence was carried out by a leadership core. Even when certain crowd members participated in a limited way, they still looked to the mob leadership to approve and orchestrate killings. When some crowd members beat two fleeing black men they did not kill them, but passed them to more active rioters, shouting "hang them" and "swing 'em up". On another occasion the crowd set two black men against a wall for three armed whites to shoot and kill. ${ }^{7}$

By the evening, patterns of behaviour in the riot had changed significantly. The "mob" leadership built on (ever-changing) norms within the enclosed riot environment, driving the riot gradually to its atrocious

74. Testimony of George E. Popkess, 22 October i917: Select Committee, pp. 384, 394-395 of transcripts of hearings (reel I, frames 4I 2, 422-423, UPA microfilm collection). See also Dr C.P. Renner, 26 October 1917: Select Committee, p. I 236 of transcripts of hearings (reel 2, frame 320, UPA microfilm collection).

75. Testimony of Paul Y. Anderson, 20 October 1917: Select Committee, pp. 264-265 of transcripts of hearings (reel I, frames 294-295, UPA microfilm collection). For "storm center", see testimony of Robert J. Baylan, 23 October I917: Select Committee, pp. 578, 604 of transcripts of hearings (reel I, frames 604, 630, UPA microfilm collection). Additionally see Roy Albertson, 22 October 1917: Select Committee, p. 492 of transcripts of hearings (reel I, frame 516, UPA microfilm collection). For "good natured [...]" see Missouri Historical Society clipping file: p. 32, "Lynchers Joke". Additionally see report of Colonel E.P. Clayton, 25 October 1917: pp. I0-I 2 of copy of report (reel 6, frames 42-44, UPA microfilm collection).

76. St Louis Republic, 3 July i917, p. I.

77. Missouri Historical Society clipping file: p. 32, "Lynchers Joke". Paul Y. Anderson noted that a "small crowd" of "fifteen or twenty" were committing the atrocities, surrounded by a large spectating crowd. See Paul Y. Anderson, 20 October 1917: Select Committee, p. 333 of transcripts of hearings (reel I, frame 426 , UPA microfilm collection). 
end. This offers an explanation for the worsening violence during the July massacre, which Rudwick's earlier work had described, but not accounted for. Furthermore, by emphasizing the different levels of participation in the riot it has been possible to provide some indication of how such a wide section of the white community could become drawn into the atrocities. Undoubtedly, that assembled crowd bears responsibility for eventually supporting indiscriminate murder. However, without prodigiously violent individuals at the core of the mob, willing to break new violent ground, it seems far from certain that the riot would have ended in bloody tumult at Fourth and Broadway.

It is possible to identify some of these riot leaders. A newspaper report mentioned a seventeen-year-old boy cooperating with a person described by newspaper reporters as "the ringleader" making improvized nooses at Fourth and Broadway. ${ }^{78}$ This is a likely reference to Herbert Wood, a forty-year-old railroad switchman, and Leo Keane, a seventeen-year-old railroad messenger who paraded one man through the streets around Fourth and Broadway by a rope and noose around his neck. It seems likely that they were involved in other hangings with Richard Brockway, whose key role in organizing the mob in the morning, and in the later lynchings, was confirmed by witnesses during his trial: Brockway was one example of a key riot leader, who clearly instigated the violence, remained at its core and eventually took a leading role in the worst of the atrocities. ${ }^{79}$

Apart from these three men, testimony given before the congressional investigation into the riot indicates strongly that patrons and employees of the city's many saloons - referred to variously as saloon "hangers-on", "saloon bums", "pimps" and "machos" - had a prominent role in the violence and later evaded justice. ${ }^{80}$ Many downtown saloons, often functioning as illegal gambling parlours and brothels, were notoriously violent places. Many patrons went "heavily armed" and, according to city coroner C.P. Renner, "lots of the homicides" were committed in these

78. Missouri Historical Society clipping file: p. 32, "Lynchers Joke".

79. Lieutenant Clayton incorrectly refers to Keane as "King" in his report. See report of Colonel E.P. Clayton, 25 October 1917: p. I I of copy of report (reel 6, frames 43, UPA microfilm collection). See Rudwick, Race Riot, p. 99-103, I07-109. Additionally, see the newspaper reports of the trials of Wood and Keane in the Daily Journal, I I October 1917, p. I, I4 October I917, p. I, and I6 October 1917. For Brockway, see the Daily Journal, 25 November 1917, p. I0. See also 21 November 1917, p. I; 22 November I917 p. I; 23 November 1917, p. I; and 25 November 1917, p. I.

80. Testimony of Paul Y. Anderson, 20 October 1917: Select Committee, pp. 28 1, 307, 358-359 of transcripts of hearings (reel I, frames 3 I I , 337, 388-389, UPA microfilm collection). See also George E. Popkess, 22 October I917: Select Committee, p. 4I 8 of transcripts of hearings (reel I, frame 438, UPA microfilm collection). Additionally see Robert J. Baylan, 23 October i9i7: Select Committee, p. 619 of transcripts of hearings (reel I, frame 644, UPA microfilm collection). See also Rudwick, Race Riot, p. 202. 
saloons. ${ }^{81}$ The evidence indicates that men who frequented downtown saloons of this kind would often encounter extreme acts of violence, and there is some persuasive power in the claim that "saloon bums" were responsible for much of the brutality, once they became involved on 2 July. It seems likely that regular exposure to violence and homicide would mould individuals with a more extreme sense of "normal" levels of violence: such individuals would be likely suspects when considering who may have been involved in the atrocities of July 2, and why a certain number of individuals emerged at the centre of the violence.

Furthermore, certain prominent downtown saloons in East St Louis were run by crime bosses - the European Hotel run by one "Fat" Johnson for example. These establishments employed professional hoodlums possibly the "pimps" or "machos" referred to in the evidence - and in newspapers and during Select Committee hearings it was said that these criminal gangsters had intimidated witnesses so they would not reveal the identities of the rioters. It would not be surprising if such individuals had become involved in the atrocities on $2 \mathrm{July.}{ }^{82}$ Moreover, interest in saloon business suggests one possible motive for participation in the riot. Not long before the riot, City Hall had sponsored a symbolic "clean-up" of some saloons owned by whites in the Valley vice district, but saloons, brothels, and gambling parlours owned by African Americans had soon after opened up in their place. Perhaps the riot offered hoodlums an opportunity to eliminate such unwelcome competition in the form of black-owned saloons. ${ }^{83}$

It is possible that hoodlums could have evaded justice because of political connections: certain saloon keepers wielded great political influence in the city and their criminal gangs benefited from a privileged relationship with the local authorities, protected by corrupt police officers and politicians. They were able to keep their (well-known) illegal saloons open in defiance of the law for years before the riot. It seems quite plausible that, had any associates of these gangs been involved in the riot, the local authorities would have allowed them to evade prosecution: "relatives of members of the city administration [...] [were] [...] in the

8I. Testimony of Dr C.P. Renner, 26 October 1917: Select Committee, pp. I238, I255 of transcripts of hearings (reel 2, frames 322, 340, UPA microfilm collection). See also J.W. Edmonson (police officer, East St Louis) I 3 November 1917: Select Committee, p. 903 of transcripts of hearings (reel 5 , frame $4 \mathrm{I} 6_{4}$, UPA microfilm collection).

82. Missouri Historical Society clipping file: p. 6, "Sherman Says". See also Paul Y. Anderson, 20 October 1917: Select Committee, pp. 358-359 of transcripts of hearings (reel I, frames 388-389, UPA microfilm collection). For "Fat" Johnson, see William A. Miller, I 3 November i 917 : Select Committee, pp. 4066-4067 of transcripts of hearings (reel 5, frames 6-7, UPA microfilm collection). See also George Allison (minister, First Baptist Church) io November 1917: Select Committee, p. 3672 of transcripts of hearings (reel 4 , frame 701 , UPA microfilm collection). 83. St Lonis Globe-Democrat, 3 July I9I7 p. 2. See also Rudwick, Race Riot, p. 48. Additionally, see St Louis Republic, 3 July i917, p. 5. 
employ of gambling house organizers" ${ }^{84}$ However, this was not simply a matter of personal corruption. Local politicians had political reasons for permitting illegal saloons to flourish, even at the cost of allowing crime to proliferate: Rudwick demonstrated that City Hall was dependent upon the revenue provided by saloon licences because the large corporate employers used their considerable influence in the city to evade taxation. In light of this, some blame must be laid on the structure of power, which allowed corporations to collude with politicians in such a way. For that indirectly resulted in the violent saloon culture of East St Louis which produced a significant number of the individuals responsible for the driving forward of the July massacre. ${ }^{85}$

\section{CONCLUSION}

Taking the key contexts of black migration and industrial conflict identified in the classic work of Elliot Rudwick, some new perspectives on the racial killings of July I9I7 have been suggested. Analysis of rumour has indicated some meanings behind the eruption of violence and cooperation between the riot mob and the police and National Guard. In particular, Jeremy Krikler's suggestion that the violence in East St Louis - as on the Rand - "was linked subconsciously to an attempt to restore that community of whites which had earlier been shattered by class conflict", seems a convincing one in light of this discussion. ${ }^{86}$ Rudwick's work noted that whites responded to black migration as if it were a threat to their community, resulting in an upsurge in racial hostility, but some new perspectives have been presented. Consideration has been given to the significance of recurring themes of pollution surrounding racial hostility, but nevertheless, this has been with an acknowledgement of the importance of the social context. It was noted that white workers drew their sense of self-esteem by reference to an ideological notion of black workers' social and economic position, which they associated with the most insecure, exploited, and deprived economic conditions imaginable. The racial violence on 2 July, then, can be seen as a lashing-out against those whom white workers feared they might become, as employers across the city, supported by the state, seemed bent on the destruction of organized labour.

Finally, to the riot mob itself: it is clear that assertive mob leaders drove the violence forward in escalating stages throughout the day on 2 July. This, it was noted, seemed to conform with the emergent norm approach

84. Rudwick, Race Riot, pp. 198-199.

85. Ibid., pp. I98-200, 206. For further social and political background, see Andrew J. Theising, "Profitable Boundaries: Incorporating the Industrial Suburb" (Ph.D. thesis, University of Missouri St Louis, 1997), pp. 9-10.

86. Krikler, "Racial Massacre”, p. I072. 
to collective behaviour. A mob leadership - distinct from the supportive crowd - can be identified and it seems likely that it had links to the brutal saloon culture of East St Louis, a saloon culture that had been cultivated by a municipal government that was dependent on saloon licences for its revenue because of its collusion with industry in corporation tax evasion. That brutal culture played a key role in the riot, and its place in the violence of 2 July invites the condemnation of City Hall and the authorities, as much as the individuals who perpetrated the atrocities. 